Sains Malaysiana 50(1)(2021): 101-107

http://dx.doi.org/10.17576/jsm-2021-5001-11

\title{
Structural Diversity, Anti-Fungal Activity and Chemosystematics of Bornean Liverwort Bazzania harpago (De Not.) Schiffner
}

(Kepelbagaian Struktur, Aktiviti Anti-Kulat dan Kemosistematik Lumut Hati Borneo Bazzania harpago (De Not.) Schiffner)

\author{
Shean-Yeaw Ng, Lee-Ping Ang, Vui-Lun Hau, Monica Suleiman, Charles Santhanaraju Vairappan \& \\ TAKASHI KAMADA*
}

\section{ABSTRACT}

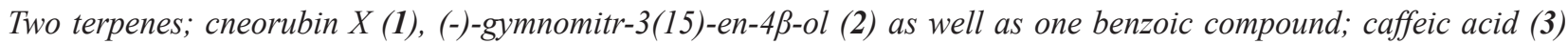
were isolated from Bazzania harpago collected from Mt. Trus Madi, Sabah, Malaysia. The structures of these secondary metabolites were elucidated based on spectroscopic data (Infra-Red (IR), 1D and 2D Nuclear Magnetic Resonance (NMR), and Mass Spectrum (MS)). This is the first record that cneorubin X (1) was isolated from non-vascular plants and it exhibited active anti-fungal activity against Haliphthoros sabahensis and Haliphthoros milfordensis. Chemosystematics finding suggests that the Marchantiophyta (liverworts) genus Bazzania might have a closer chemical relationship to its sister group Bryophyta (mosses) genus Brachythecium, Kindbergia and Mnium, as well as Anthocerophyta (hornworts) genus Anthoceros in their evolutionary history.

Keywords: Bazzania harpago; Borneo; chemosystematics; liverwort; secondary metabolite

\section{ABSTRAK}

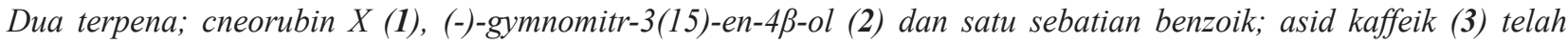
diasingkan daripada Bazzania harpago yang diambil dari Gunung Trus Madi, Sabah, Malaysia. Struktur metabolit sekunder ini telah dijelaskan berdasarkan data spektroskopi (Infra-merah (IR), 1D and 2D Resonans Magnet Nukleus (NMR) dan Spektrum Jisim (MS)). Kajian ini merupakan rekod pertama cneorubin X (1) yang diasingkan daripada tumbuhan bukan vaskular serta menunjukkan aktiviti anti-kulat yang aktif terhadap Haliphthoros sabahensis dan Haliphthoros milfordensis. Hasil kajian mencadangkan bahawa Marchantiophyta (lumut hati) genus Bazzania mempunyai hubungan kimia yang lebih rapat dengan kumpulan kembarnya, briofit (lumut hati) genus Brachythecium, Kindbergia dan Mnium, begitu juga dengan Anthocerophyta (lumut tanduk) genus Anthoceros dalam sejarah evolusi mereka.

Kata kunci: Bazzania harpago; Borneo; lumut hati; metabolit sekunder; sistematik kimia

\section{INTRODUCTION}

Bryophytes can be classified into three divisions, namely Bryophyta (mosses), Marchantiophyta (liverworts) and Anthocerotopyhta (hornworts) (Crandall-Stotler et al. 2009). The number of bryophytes species is approximately 24,000 species whereby 14,000 species are mosses, 6,000 species are liverworts, and 300 species are hornworts (Asakawa et al. 2013a). Tropical rainforest of Borneo is one of the 12 mega-biodiversity hotspots on Earth possessing extremely high species richness and abundance of flora and fauna, including high number of endemic liverworts (Ariyanti et al. 2008). There is a total of 38 families, 122 genera and 758 taxa of liverworts can be found in Sabah (Chuah-Petiot 2011). The characteristics that differentiate liverworts from other bryophytes are the present of cellular oil bodies (Asakawa et al. 2013b). There are various types of oil bodies and the oil bodies often produce secondary metabolites which mostly composed of lipophilic terpenoids and aromatic compounds. Asakawa (2004) and Asakawa et al. (2013a) reported that secondary metabolites from liverworts showed various biological activities such as cytotoxic, insect anti-feedant, insecticidal, muscle relaxing, antimicrobial and anti-inflammation activities.

The genus Bazzania consists one of the most diverse number of liverwort species in the family of Lepidoziaceae. Out of the 150 Bazzania species worldwide, 24 of them could be found in Sabah; $B$. conophylla, $B$. densa, B. eurosa, B. indica, B. intermedia, B. friabilis, $B$. grandiretis, B. harpago, B. horridula, B. involutiformis, 
B. kokawana, B. longicaulis, B. lowii, B. marginela, B. parvitexta, B. patentistipa, B. praerupta, B. psedovittata, $B$. spiralis, B. subtilis, B. tridens, B. uncigera, $B$. vittata, and $B$. serpentina (Chuah-Petiot 2011; Frahm et al. 1990; Menzel 1988). Globally, the phytochemical analysis of Bazzania has been studied extensively in liverwort and they have been shown to produce a wide diversity of sesquiterpenoids and aromatic compounds (Asakawa 2004; Asakawa et al. 2013b). Figure 1 shows the chemical skeleton of the studied Bazzania species. However, the phytochemical information of the Bornean Bazzania is still not well understood. To date, there are only three species of Bornean Bazzania that have been chemically investigated which are $B$. harpago, $B$. praerupta, and $B$. spiralis. Interestingly, although $B$. harpago, B. praerupta, and B. spiralis are of the same genus, they are not chemically related due to the origin of their major metabolites' chemical skeleton. Barbatanes are characteristic of $B$. harpago, whereas drimanes are characteristics of $B$. praerupta and eudesmanes are characteristics of $B$. spiralis (Ludwiczuk \& Asakawa 2010).

As part of our on-going interest in bioactive secondary metabolites from Bornean liverworts, we have obtained two terpenes as well as one benzoic compound from Bazzania harpago (De Not.) Schiffner collected at Mt. Trus Madi, Sabah, Malaysia. The isolation of these metabolites, their antifungal activity and chemosystematics are reported in this paper.

\section{MATERIALS AND METHODS}

\section{GENERAL}

Using deuterated chloroform $\left(\mathrm{CDCl}_{3}\right)$ with tetramethylsilane (TMS) as an internal standard, the NMR spectra were obtained via $600 \mathrm{MHz}$ FT-NMR (Jeol, Japan). The high-resolution mass spectrum was acquired on Liquid Chromatography-Electrospray Ionization-Ion Trap-Time of Flight-Mass Spectrometry (Shimadzu, Japan). The optical rotation was measured at $25{ }^{\circ} \mathrm{C}$ using AUTOPOL IV automatic polarimeter (Rudolph Research Analytical, USA). Infrared spectra were recorded on a FTIR spectroscopy (Thermo Nicolet, USA). For purification and compounds isolation, Silica gel preparative TLC (Kieselgel 60, $\mathrm{F}_{254}$ ) and column chromatography (Kieselgel 60, 70-230 mesh) were performed (Merck, Germany).

\section{SAMPLES COLLECTION}

Specimen of Bazzania harpago (M. Suleiman \& S.Y. $\mathrm{Ng}$ 5947) was collected from Mt. Trus Madi (5 ${ }^{\circ} 33^{\prime}$ 29.736'N, $\left.116^{\circ} 29^{\prime} 59.1^{\prime \prime} \mathrm{E}\right)$, Sabah, Malaysia on 20th August 2015. Identification was carried out by the forth author (Universiti Malaysia Sabah) and a voucher specimen (BORB0024) is deposited in the
BORNEENSIS Herbarium of Institute for Tropical Biology and Conservation (BORH), Universiti Malaysia Sabah. The sample was brought back to the laboratory under cool conditions $\left(4^{\circ} \mathrm{C}\right)$ and processed according to the procedures described by $\mathrm{Ng}$ et al. (2016).

\section{EXTRACTION AND ISOLATION}

Specimens of plant material $(201 \mathrm{~g})$ were air-dried and extracted with methanol $(\mathrm{MeOH})$ at room temperature (1.0 $\mathrm{L} \times 3$ for 3 days). Solvent partition of the crude extract was performed between ethyl acetate (EtOAc) $(50 \mathrm{~mL} \times$ $3)$ and distilled water $(150 \mathrm{~mL})$. The combined organic layers were dried over sodium sulfate (anhydrous) and concentrated in vacuo to afford EtOAc extract of $2.1 \mathrm{~g}$ in weight. The EtOAc extracts ( $1 \mathrm{~g})$ was chromatographed using a gravitational Silica gel column using n-hexane (Hex) and EtOAc solvent system as eluent with increasing polarity Hex/EtOAc: 9:1, 8:2, 7:3, 1:1 and $100 \%$ EtOAc) to yield five fractions, $1-5$. The obtained respective compounds yields were calculated as percentages in the EtOAc crudes.

Fraction 2 (162.6 mg) was subjected to PTLC (Hex/ EtOAc: $9: 1)$ to yield $1(27.1 \mathrm{mg})(2.7 \%$ yield). Fraction 4 $(227.2 \mathrm{mg})$ was subjected to PTLC $\left(100 \% \mathrm{CHCl}_{3}\right)$ to yield 2 (80.1 mg) (8.0\% yield) and 3 (83.8 mg) (8.4\% yield).

\section{ANTI-FUNGAL ACTIVITY}

The minimum inhibitory concentration (MIC) of fungistatic effect on hyphae was determined. Different concentrations of the pure compound solutions (12.5, $25,50,100 \mu \mathrm{g} / \mathrm{mL}$ ) were incorporated onto Peptone Yeast Extract Glucose Sugar (PYGS) agar in petri dish followed by inoculation of the Lagenidium thermophilum, Haliphthoros sabahensis, and Haliphthoros milfordensis. The procedure was adopted from Munchan et al. (2009) with slight modification. After incubated at $25{ }^{\circ} \mathrm{C}$ for a week, the lowest concentration of agar which showed no visible hyphal growth was determined as the MIC.

\section{RESULTS AND DISCUSSION}

Approximately $201 \mathrm{~g}$ of Bazzania harpago was collected from Mt. Trus Madi (Figure 2). Upon extraction and partition process as described above, $2.1 \mathrm{~g}$ of EtOAc extract was obtained from $B$. harpago. The cellular oil bodies of the $B$. harpago specimen is as shown in Figure 3.

The structures of 1-3 were elucidated based on extensive analysis of spectroscopic data and comparison with those published literatures. The compounds cneorubin X (1) (Brochini \& Roque 2000),

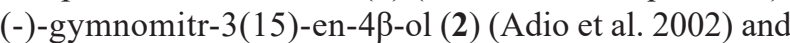
caffeic acid (3) (Jocković et al. 2008) were identified. Chemical structures of the compound $\mathbf{1}$ to $\mathbf{3}$ are shown in Figure 4. 
The minor compound $\mathbf{1}$ was isolated as colourless oil with $[\mathrm{a}]_{D}^{\mathcal{Z}}:-19.0\left(\right.$ c $\left.0.30, \mathrm{CHCl}_{3}\right)$. The molecular formula of $1, \mathrm{C}_{20} \mathrm{H}_{32} \mathrm{O}$ (corresponding to five degree of unsaturation), was deduced from HR-ESI-MS measurements. The IR absorption at $3370 \mathrm{~cm}^{-1}$ indicated the presence of the hydroxyl group. HSQC and ${ }^{13} \mathrm{C}$-DEPT experiments coupled with ${ }^{13} \mathrm{C}$ - and ${ }^{1} \mathrm{H}-\mathrm{NMR}$ signals of compound 1 showed the presence of an olefinic carbons at $\delta_{\mathrm{C}} 131.9(\mathrm{C}), \delta_{\mathrm{C}} 125.5(\mathrm{CH}), \delta_{\mathrm{H}} 5.10(1 \mathrm{H}, \mathrm{t})$, one vinylidene at $\delta_{\mathrm{C}} 154.2(\mathrm{C}), \delta_{\mathrm{C}} 106.9\left(\mathrm{CH}_{2}\right), \delta_{\mathrm{H}} 4.68(2 \mathrm{H}, \mathrm{d})$, four methyls at $\delta_{\mathrm{C}} 26.4\left(\mathrm{CH}_{3}\right), \delta_{\mathrm{H}} 1.68(3 \mathrm{H}, \mathrm{s}), \delta_{\mathrm{C}} 26.4\left(\mathrm{CH}_{3}\right), \delta_{\mathrm{H}} 1.30(3 \mathrm{H}$, $\mathrm{s}), \delta_{\mathrm{C}} 18.3\left(\mathrm{CH}_{3}\right), \delta_{\mathrm{H}} 1.60(3 \mathrm{H}, \mathrm{s}), \delta_{\mathrm{C}} 14.4\left(\mathrm{CH}_{3}\right), \delta_{\mathrm{H}} 1.03$ $(3 \mathrm{H}, \mathrm{s})$, six methylenes, four methines and two quaternary carbons including one bearing hetero atom (Table 1). Hence, degree of unsaturation could be attributed to two double bonds and three rings.

Two spin systems were unveiled by the analysis of ${ }^{1} \mathrm{H}-{ }^{1} \mathrm{H}$ COSY experiment. The HMBC correlations of $\mathrm{H}_{3}-15$ with $\mathrm{C}-3, \mathrm{C}-4$ and $\mathrm{C}-5$ allowed us to deduce connectivity of $\mathrm{C}-15$ to $\mathrm{C}-4$. The $\mathrm{HMBC}$ correlations of $\mathrm{H}_{3}-13$ with $\mathrm{C}-6, \mathrm{C}-7, \mathrm{C}-11$ and $\mathrm{C}-12$ allowed us to attach $\mathrm{C}-13$ to $\mathrm{C}-11$. Besides, the three-bond correlations of $\mathrm{H}_{3}-19$ and $\mathrm{H}_{3}-20$ to the opposite carbons $\mathrm{C}-19$ and $\mathrm{C}-20$, and the correlations of both to $\mathrm{C}-17$ and $\mathrm{C}-18$, permitted placement of the gem-dimethyl group at C-18. The exomethylene group attached between C-1 and C-9 was confirmed by HMBC correlations of $\mathrm{H}_{2}-14$ to $\mathrm{C}-1$ and C-9. Evidences from the finding suggested the gross structure of 1 as shown in Figure 4. The NOESY experiment and comparison with published literature concluded the relative stereochemistry of $\mathbf{1}$ (Brochini \& Roque 2000). Thus, compound 1 was identified as cneorubin X (Figure 4). The previously assignment of proton chemical shift at $\mathrm{H}-8 \alpha$ and $\mathrm{H}-12 \alpha$ are different from our present results (Brochini \& Roque 2000; Hernandez et al. 2018). This could be explained by the usage of lower megahertz NMR machine which gave inaccurate results $(200 \mathrm{MHz}$ NMR) compared to our present study (600 MHz NMR).

The anti-fungal activity was carried out using all the isolated metabolites against three selected marine fungi, Lagenidium thermophilum IPMB 1401, Haliphthoros sabahensis IPMB 1402, Haliphthoros milfordensis IPMB 1603. Among the three tested compounds, compound 1 showed the best anti-fungal activity against $H$. sabahensis and $H$. milfordensis, both with MIC value of $25 \mathrm{mg} / \mathrm{mL}$. The anti-fungal results of the isolated metabolites were as shown in Table 2.

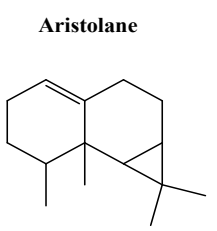

Elemane<smiles>C=CC1CCC(C)(C=C)C(C)C1</smiles>

Cadinane<smiles>CC1=CC2=C(CC1)C(C)CCC2C(C)C</smiles>

Chamigrane<smiles>C=C1CCCC(C)(C)C12CC=C(C)CC2</smiles>

Daucane<smiles>CC1=CCC2(C)CCC(=C(C)C)C2CC1</smiles><smiles>C=C1CCCC(C)(C)[C@]2(C)C=C(C)CC[C@H]12</smiles>

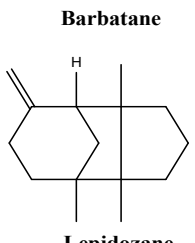

Bicyclogemacrane<smiles>CC1=CCCC(C=O)=CCC1C1CC1C</smiles><smiles>Cc1ccc2c(c1)C(C(C)C)CCC2C</smiles>

Cuparane<smiles>CC1=CCC23C(C)CCC(C(C)C)C2C13</smiles><smiles>CC1=CC=C(C2(C)CCCC2(C)C)CC1</smiles><smiles>C=C(CCCC(C)C)c1ccc(C)cc1</smiles>

Caryophyllane

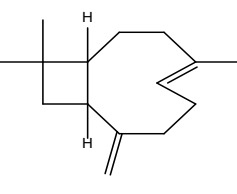

Herbertane

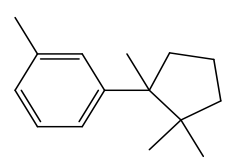<smiles>C=C1C(C)=CCC2C(C)(C)CCCC12C</smiles><smiles>C=C(C)C1CCC2(C)CCC=C(C)C2C1</smiles><smiles>CC1CCC2(C)C(=CC(C(C)(C)O)CCC2C)C1</smiles><smiles>CC1=CCCC(C)=CCC(C)(C)C=CC1</smiles><smiles>CC1=CC[C@H]2[C@@H](C)CCCC(C)(C)[C@@H]12</smiles><smiles>CC1C2CCC3(C)CCCC(C)(O)C3(C)C12</smiles>

FIGURE 1. Characteristic chemical skeleton isolated from studied Bazzania species worldwide 


\section{CHEMOSYSTEMATIC OF BORNEAN LIVERWORTS}

Cneorubin X (1) was isolated from sample Bazzania harpago. Literature reviews showed that $\mathbf{1}$ was initially isolated and reported from Cneorum tricoccon (Trautmann et al. 1980), Guarea guidonia (Brochini \& Roque 2000), Ptaeroxylon obliquum (Mulholland \& Mahomed 2000) and Trichilia sylvatica (Soares et al. 2014), that are all vascular plants. To the best of our knowledge, this is the first report of Cneorubin $\mathrm{X}$ been reported from a non-vascular plant. This unique diterpenoid was absence in previous phytochemical analysis of $B$. harpago collected from Mount Kinabalu conducted by Ludwiczuk and Asakawa (2010). This might be due to the differences of genetics, environmental variation or microhabitat differences from two mountain areas ( $\mathrm{Ng}$ et al. 2017). Besides, it is also

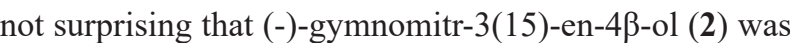
found as the major metabolites in this specimen since these Barbatane-type metabolites are known to be the characteristic of B. harpago (Asakawa 1982). Interestingly, the caffeic acid (3) which only presented from some mosses genera such as Brachythecium, Kindbergia, and Mnium, as well as in hornworts genus Anthoceros, was only reported in liverworts genus Bazzania (Asakawa 1995; Asakawa et al. 2013b). This finding suggests that the Marchantiophyta (liverworts) genus Bazzania might have a closer chemical relationship to its sister group Bryophyta (mosses) genus Brachythecium, Kindbergia, and Mnium, as well as Anthocerophyta (hornworts) genus Anthoceros in their evolutionary history.

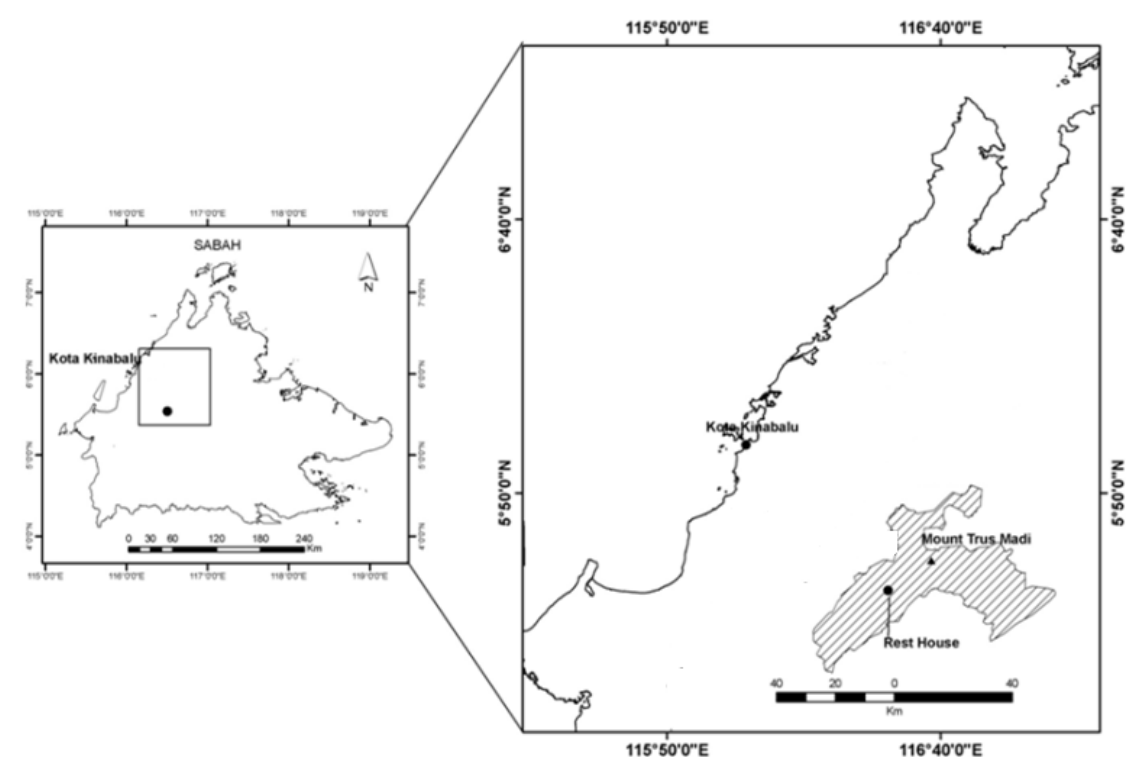

FIGURE 2. Map of sample collection site

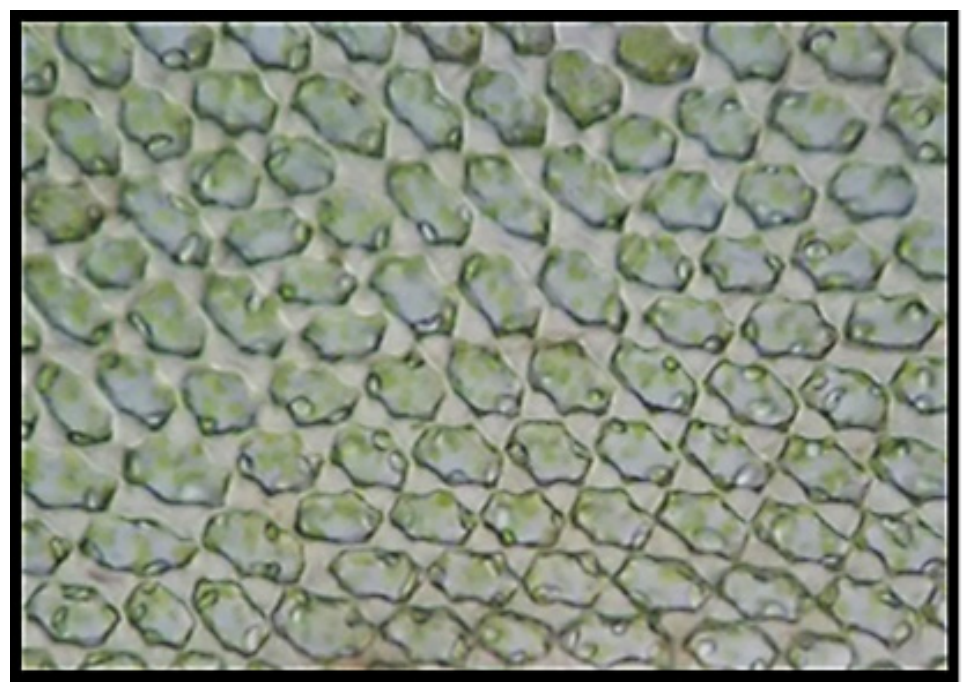

FIGURE 3. Oil bodies of Bazzania harpago specimen 

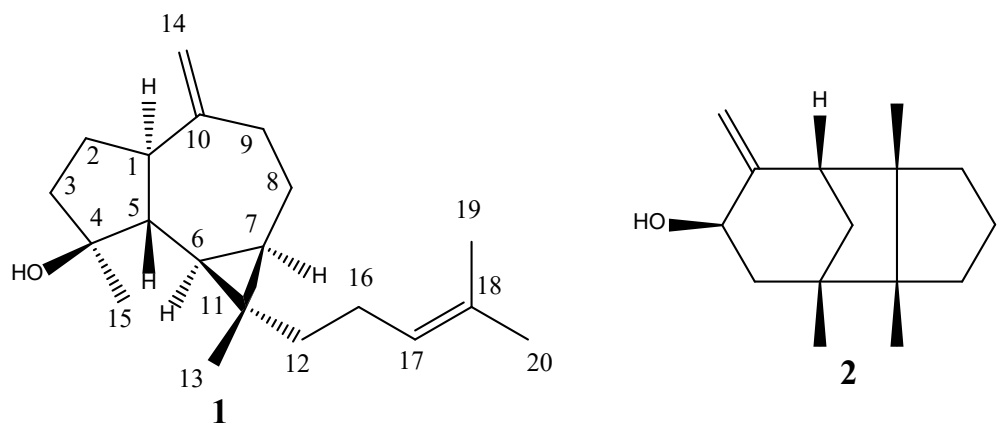<smiles>O=C(O)/C=C/c1ccc(O)c(O)c1</smiles>

FIGURE 4. Structures of isolated compounds 1-3

TABLE $1 .{ }^{13} \mathrm{C}-\mathrm{NMR}(150 \mathrm{MHz})$ and ${ }^{1} \mathrm{H}-\mathrm{NMR}(600 \mathrm{MHz})$ data for $\mathbf{1}$

\begin{tabular}{|c|c|c|c|c|c|}
\hline \multirow[b]{2}{*}{$\mathrm{C}^{b}$} & \multicolumn{3}{|c|}{1} & \multicolumn{2}{|c|}{$\begin{array}{c}\text { Literature } \\
\text { (Brochini \& Roque 2000) }\end{array}$} \\
\hline & ${ }^{13} \mathrm{C}(\delta)$ & ${ }^{1} \mathrm{H}(\delta)$ & multiplicity, $J(\mathrm{~Hz})$ & ${ }^{13} \mathrm{C}(\delta)$ & ${ }^{1} \mathrm{H}(\delta)$ \\
\hline 1 & 52.9 & 2.22 & $\mathrm{~m}$ & 52.9 & 2.19 \\
\hline $2 \alpha$ & 26.3 & 1.62 & $\mathrm{~m}$ & 26.3 & \\
\hline $2 \beta$ & & 1.89 & $\mathrm{~m}$ & & \\
\hline $3 \alpha$ & 41.6 & 1.60 & $\mathrm{~m}$ & 41.6 & \\
\hline $3 \beta$ & & 1.76 & $\mathrm{~m}$ & & \\
\hline 4 & 81.1 & & & 81.0 & \\
\hline 5 & 53.8 & 1.34 & $\mathrm{~m}$ & 53.8 & 1.32 \\
\hline 6 & 29.1 & 0.49 & $\mathrm{dd}, J=9.6,11.0$ & 29.1 & 0.48 \\
\hline 7 & 26.8 & 0.72 & $\mathrm{~m}$ & 26.8 & 0.71 \\
\hline $8 \alpha$ & 24.8 & 1.01 & $\mathrm{~m}$ & 24.8 & 0.90 \\
\hline $8 b$ & & 1.97 & $\mathrm{~m}$ & & 2.01 \\
\hline $9 \alpha$ & 38.9 & 2.03 & $\mathrm{~m}$ & 38.9 & \\
\hline $9 \beta$ & & 2.42 & $\mathrm{dd}, J=6.2,13.8$ & & 2.40 \\
\hline 10 & 153.5 & & & 153.5 & \\
\hline 11 & 24.3 & & & 24.3 & \\
\hline $12 \alpha$ & 43.3 & 1.14 & $\mathrm{~m}$ & 43.2 & 1.03 \\
\hline $12 \beta$ & & 1.34 & $\mathrm{~m}$ & & 1.37 \\
\hline 13 & 13.7 & 1.03 & $\mathrm{~s}$ & 13.6 & 1.02 \\
\hline $14 \alpha$ & 106.2 & 4.68 & $\mathrm{~d}, J=17.2$ & 106.2 & 4.65 \\
\hline $14 b$ & & 4.68 & $\mathrm{~d}, J=17.2$ & & 4.68 \\
\hline 15 & 25.9 & 1.30 & $\mathrm{~s}$ & 25.7 & 1.28 \\
\hline $16 \alpha$ & 25.2 & 2.03 & $\mathrm{~m}$ & 25.2 & 2.09 \\
\hline $16 \beta$ & & 2.06 & $\mathrm{~m}$ & & \\
\hline 17 & 124.8 & 5.10 & $\mathrm{t}, J=6.9$ & 124.8 & 5.10 \\
\hline 18 & 131.2 & & & 131.1 & \\
\hline 19 & 17.6 & 1.60 & s & 17.6 & 1.59 \\
\hline 20 & 25.7 & 1.68 & $\mathrm{~s}$ & 25.9 & 1.66 \\
\hline
\end{tabular}


TABLE 2. Minimum inhibitory concentration (MIC) of isolated secondary metabolites against the selected marine fungi

\begin{tabular}{cccc}
\hline Fungus strain & $\begin{array}{c}\text { Lagenidium } \\
\text { thermophilum }\end{array}$ & $\begin{array}{c}\text { Haliphthoros } \\
\text { sabahensis }\end{array}$ & $\begin{array}{c}\text { Haliphthoros } \\
\text { milfordensis }\end{array}$ \\
\cline { 2 - 4 } Compounds & MIC $(\mathrm{mg} / \mathrm{mL})$ & MIC $(\mathrm{mg} / \mathrm{mL})$ & MIC (mg/mL) \\
\hline $\mathbf{1}$ & 50 & 25 & 25 \\
$\mathbf{2}$ & 100 & 100 & 100 \\
$\mathbf{3}$ & 100 & 100 & 100 \\
\hline
\end{tabular}

\section{CONCLUSION}

In conclusion, presented finding is the first report on the isolation of cneorubin X (1) from non-vascular plant B. harpago. Barbatane-type of secondary metabolites represents the chemotaxonomical marker for Bornean B. harpago and these secondary metabolites displayed antifungal activity against three marine fungi. Chemosystematics results showed that liverworts genus Bazzania has an evolutionary closer chemical relationship to certain mosses genera (Brachythecium, Kindbergia, Mnium) and hornworts genus (Anthoceros).

\section{ACKNOWLEDGEMENTS}

This research was financially supported by the Sabah Biodiversity Centre (GL0070) and Universiti Malaysia Sabah (SBK0258-SG-2016). The authors would like to thanks Sabah Forestry Department for the support given during field sampling. Appreciation would go to Japan Society for the Promotion of Science KAKENHI (19H03308) for funding the transportation which yielded a fruitful discussion pertaining to the publication of the current journal article. The authors also wish to express gratitude to Shizuoka Institute of Science and Technology for guidance in literature search funded through research project $\mathrm{A}$.

\section{REFERENCES}

Adio, A.M., Paul, C., König, W.A. \& Muhle, H. 2002. Volatile components from European liverworts Marsupella emarginata, M. aquatic and M. alpina. Phytochemistry 61(1): 79-91.

Ariyanti, N.S., Bos, M.M., Kartawinata, K., Tjitrosoedirdjo, S.S., Guhardja, E. \& Gradstein, S.R. 2008. Bryophytes on tree trunks in natural forest, selectively logged forests and cacao agroforests in Central Sulawesi, Indonesia. Biological Conservation 141(10): 2516-2527.

Asakawa, Y. 2004. Chemosystematics of the Hepaticae. Phytochemistry 65(6): 623-669.
Asakawa, Y. 1995. Chemical constituents of the Bryophytes. In Progress in the Chemistry of Organic Natural Products, edited by Herz, W., Kirby, G.W., Moore, R.E., Steglich, W. \& Tamm, Ch. Vienna: Springer. pp. 1-618.

Asakawa, Y. 1982. Chemical constituents of Hepaticae. In Progress in the Chemistry of Organic Natural Products, edited by Herz, W., Grisebach, H. \& Kirby, G.W. Vienna: Springer. pp. 1-285.

Asakawa, Y., Ludwiczuk, A. \& Nagashima, F. 2013a. Phytochemical and biologica studies of bryophytes. Phytochemistry 91: 52-80.

Asakawa, Y., Ludwiczuk, A. \& Nagashima, F. 2013b. Chemical constituents of bryophytes. In Progress in the Chemistry of Organic Natural Products, edited by Kinghorn, A.D., Falk, H. \& Kobayashi, J. Vienna: Springer. pp. 1-796.

Brochini, C.B. \& Roque, N.F. 2000. Two new cneorubin related diterpenes from the leaves of Guarea guidonia (Meliaceae). Journal of the Brazillian Chemical Society 11(4): 361-364.

Chuah-Petiot, M.S. 2011. A checklist of Hepaticae and Anthocerotae of Malaysia. Polish Botanical Journal 56(1): 1-44.

Crandall-Stotler, B.J., Stotler, R.E. \& Long, D.G. 2009. Phylogeny and classification of the Marchantiophyta. Edinburgh Journal of Botany 66(1): 1-44.

Frahm, J.P., Frey, W., Kürschner, H. \& Menzel, M. 1990. Mosses and Liverworts of Mt. Kinabalu. Kota Kinabalu: Sabah Parks Trustees. pp. 12(2): 1-91.

Hernandez, V., De Leo, M., Cotugno, R., Braca, A., De Tommasi, N. \& Severino, L. 2018. New tirucallane-type triterpenoids from Guarea guidonia. Planta Medica 84(910): 716-720.

Jocković, N., Andrade, P.B., Valentão, P. \& Sabovljević, M. 2008. HPLC-DAD of phenolics in bryophytes Lunularia cruciata, Brachytheciastrum velutinum and Kindbergia praelonga. Journal of the Serbian Chemical Society 73(12): 1161-1167.

Ludwiczuk, A. \& Asakawa, Y. 2010. Chemosystematics of selected liverworts collected in Borneo. Tropical Bryology 31: 33-42.

Menzel, M. 1988. Annotated catalogue of the Hepaticae and Anthocerotae of Borneo. Journal of Hattori Botanical Laboratory 65: 145-206. 
Mulholland, D.A. \& Mahomed, H.A. 2000. Isolation of Cneorubin X, an unusual diterpenoid from Ptaeroxylon obliquum (Ptaeroxylaceae). Biochemical Systematics and Ecology 28(7): 713-716.

Munchan, C., Hatai, K., Takagi, S. \& Yamashita, A. 2009. In vitro and in vivo effectiveness of itraconazole against Ochroconis humicola isolated from fish. Aquaculture Science 57(3): 399-404.

Ng, S.Y., Kamada, T. \& Vairappan, C.S. 2017. New pimaranetype diterpenoid and ent-eudesmane-type sesquiterpenoid from Bornean liverwort Mastigophora diclados. Records of Natural Products 11(6): 508-513.

Ng, S.Y., Kamada, T., Suleiman, M. \& Vairappan, C.S. 2016. A new Seco-Clerodane-type diterpenoid from Bornean liverwort Schistochila acuminata. Natural Product Communications 11(8): 1071-1072.

Soares, A.D.O., Ferreira, A.G.L., Soares, L.R., Corsino, J., Garcez, F.R. \& Garcez, W.S. 2014. Chemical study of leaves of Trichilia silvatica (Meliaceae). Química Nova 37: 14871490.
Trautmann, D., Epe, B., Oelberman, U. \& Mondon, A. 1980. Diterpene aus Cneoraceen, I. Konstitution und Konfiguration der Cneorubine. Chemische Berichte 113(12): 3848-3865.

Shean-Yeaw Ng, Lee-Ping Ang, Vui-Lun Hau, Monica Suleiman, Charles Santhanaraju Vairappan \& Takashi Kamada* Institute for Tropical Biology and Conservation

Universiti Malaysia Sabah, Jalan UMS

88400 Kota Kinabalu, Sabah

Malaysia

Takashi Kamada*

Department of Materials and Life Science

Faculty of Science and Technology

Shizuoka Institute of Science and Technology

2200-2 Toyosawa, Fukuroi, Shizuoka 437-8555

Japan

*Corresponding author; email: takashi.kamada800@gmail.com

Received: 12 December 2019

Accepted: 2 July 2020 